\title{
The Importance of Female Judge Representation in the Constitutional Court of Indonesia to Achieve Gender Equality during Judicial Review Procedure
}

\author{
Natasya Fila Rais ${ }^{1 *}$ \\ ${ }^{1}$ Faculty of Law, Universitas Indonesia, Depok, West Java, Indonesia
}

\begin{abstract}
The paper will discuss about how important the female judge representation in Indonesia's Constitutional Court in order to achieve equality between genders during the process of judicial review. The Constitutional Court of Indonesia was created as a body that has the eligibility to review constitutionality under the constitution. One of the jurisdictions that the Constitutional Court of Indonesia has is to conduct judicial review. One of the elements that is needed to be achieved in the process is gender equality, in which a legislation not only guarantee lives of Indonesians as citizens with human rights, but also guarantee the equality of genders. This needs to be upheld in order to eliminate gender biased substances in legislations. Gender biased legislations will lead to disadvantages for genders. For example, the civil relations between a mother and a child born outside wedlock and the age limitation in marriage in the Indonesian Marriage Act. One of the solutions that can be done in order to eliminate gender bias clauses in legislations is by adding female representatives in the Constitutional Court. There is only one out of nine female judge listed in The Constitutional Court of Indonesia. This is seen as a problem, because in terms of reviewing clauses that give women disadvantages, there is only one woman perspectives in male-dominated panel. The research methodology used in this paper is through literature review by examining the process of judicial review. The author also uses literature review and juridical analysis to examine cases regarding genderbiased legislations. In order to examine the legislations, the author uses case study based on the judicial review verdict on the stated legislations. The author also uses literature review to examine secondary quantitative data on gender representations in the Constitutional Court.
\end{abstract}

\section{Introduction}

\subsection{Background}

The Constitutional Court of Indonesia was created as a body that has the eligibility to review constitutionality under the constitution. One of the jurisdictions that the Constitutional Court of Indonesia has is to conduct judicial review. Judicial review uses constitutional approach in order to review legislations, so any misleading in the process of

\footnotetext{
*Corresponding email : natasya.filarais@gmail.com
} 
the creation of legislations will be examined based on the Indonesian Constitution of 1945. There are several factors that needs to be considered in order to achieve fair judicial review process. In order to review a legislation with an output that is not biased, reviewers have to look upon factors, such as the social economical background, gender background, and its implementation in the future. One of the elements that is needed to be achieved in the process is gender equality, in which a legislation not only guarantee lives of Indonesians as citizens with human rights, but also guarantee the equality of genders. This needs to be upheld in order to eliminate gender biased substances in legislations. Gender biased legislations will lead to disadvantages for genders. For example, the civil relations between a mother and a child born outside wedlock and the age limitation in marriage in the Indonesian Marriage Act. One of the solutions that can be done in order to eliminate gender bias clauses in legislations is by adding female representatives in the Constitutional Court. There is only one out of nine female judge listed in The Constitutional Court of Indonesia. This is seen as a problem, because in terms of reviewing clauses that give women disadvantages, there is only one woman's perspectives in male-dominated panel.

\subsection{Research Purpose}

The aim of this paper is to examine the importance of female judge representations in the Constitutional Court of Indonesia, including concrete solutions in order to achieve gender equality in the court. The paper also shows examples of legislations that can be considered as gender biased before it has been reviewed in the Constitutional Court and it is affected by the gender imbalance of the judge panel of the Indonesian Constitutional Court.

\subsection{Hypothesis}

The hypothesis of this research is the Constitutional Court of Indonesia still suffers from gender inequality and it affects the judicial review process at the Indonesian Constitutional Court, especially reviews on gender-biased legislations.

\subsection{Methodology}

The research methodology used in this paper is through literature review by examining the process of judicial review. The author also uses literature review and juridical analysis to examine cases regarding gender-biased legislations. In order to examine the legislations, the author uses case study based on the judicial review verdict on the stated legislations. The author also uses literature review to examine secondary quantitative data on gender representations in the Constitutional Court.

\section{Analytical Framework and Analysis}

\subsection{The History of Female Representation in the Indonesian Constitutional Court Judge Panel}

The Indonesian Constitutional Court was created on August 16, 2003 based on the third amendment of the 1945 Indonesian Constitution [1]. The court is known as 'the Guardian of the Constitution', in which its vision is to guard the upholding process of constitutional 
trial independently, impartially, and fair [2]. The Indonesian Constitutional Court also aims to build a constitutional trial system that is able to uphold the constitution and to raise awareness on Indonesian citizens' constitutional rights [3]. At first, the Constitutional Court was created in order to occupy judicial review process. However, the court is developed to also handling disputes between state institutions, disputes during election, dismissal of political party, and giving out consideration regarding impeachment. Every case handled in the Indonesian Constitutional Court will be decided by a panel of judges who will create a verdict on the request.

The judge panel in the Indonesian Constitutional Court consists of nine judges. In terms of amount of judges, it is considered that odd-numbered amount of judges is the best way to create a fair decision, as well as to avoid any balanced decisions. In order to be a judge for the Indonesian Constitutional Court, each judge has to be proposed by either the President of Indonesia, the House of Representatives of Indonesia, or the Supreme Court of Indonesia. Until 2018, the Indonesian Constitutional Court judge panel is consisted of Dr. Anwar Usman, S.H., M. as the head of the judge panel with Prof. Dr. Aswanto, S.H. , M. Si., DFM. as the vice head, with members such as, Prof. Dr. Arief Hidayat, S.H., M.S., Prof. Dr. Maria Farida Indrati, S.H., M.H., Dr. Wahiduddin Adams, SH., M.A., Dr. I Dewa Gede Palguna, S.H., M.Hum., Dr. Suhartoyo, S.H., M.H., Dr. Manahan M. P. Sitompul, S.H., M.Hum., and Prof. Dr. Saldi Isra., S.H., MPA [4]. In terms of female judge in the Indonesian Constitutional Court, it is recorded that Prof. DR. Maria Farida Indrati, S.H., M.H. is the first and only female judge in the Indonesian Constitutional Court judge panel to date [5].

\subsection{The Process of Judicial Review on Gender-Biased Legislations in Indonesia and the Role of Female Judge in the Judicial Review Process}

According to the Article 50 Act number 24 year 2003, judicial review is allowed only towards legislations that are created after the amendment of the 1945 Indonesian Constitution. The subjects who are allowed to request judicial review include an individual person, a group of Indonesian traditional society, a public or private legal entity, or a state institution. The review itself is conducted in order to avoid any form of unconstitutionality in legislations. Several legislations have been reviewed by the Indonesian Constitutional Court and there are numbers of legislations which were considered as gender-biased before it was reviewed by the judge panel. In the process of reviewing gender-biased legislations, the role of coming up with a dissenting opinion plays the most important role to create a decision that does not harm women's rights in the process of the legislation implementation. Based on the history of gender-biased legislation judicial review verdicts which will be discussed on the next paragraph, female judge in the Indonesian Constitutional Court gives out a fresher perspective on the case which aims not to leave out women's views on the legislations.

As the first and only female judge in the Indonesian Constitutional Court, Prof. Dr. Maria Farida Indrati, S.H., M.H. is viewed as a female judge who succeeds in giving out female perspectives in judicial review process, as well as considering women's future fate once the legislation is regulated. She has been involved in several cases that determines the rights of Indonesian women in society. The constitutional norms are still being upheld without eliminating women's involvement in the legislation. For example, on the case of judicial review on Indonesia's Marriage Act Number 1 Year 1974 regarding a child who was born outside wedlock and its civil relations to his father [6]. Prof. Dr. Maria Farida Indrati, S.H., M.H. stated an opinion that the child was allowed to have civil relations with the father instead of only having a relation with the mother. The verdict considered that if a child only had a relation with the mother because it was based on the biological connection 
during birth, it would allow the father of the child to get away from his responsibilities as the biological father of the child. Another gender-biased case that was brought to the Indonesian Constitutional Court was a judicial review on the age limit in marriage on the Indonesian Marriage Act. Prof. Dr. Maria Farida Indrati, S.H., M.H. was the only judge who stated a dissenting opinion. The rest of the judges of the Constitutional Court refused to change the age limit of marriage for female, from 16 years old to 18 years old. However, Prof. Dr. Maria Farida Indrati, S.H., M.H. stated a dissenting opinion that said on the Article 1 and the General Provision Number 4 Point a and d of the Marriage Act, it was stated that marriage was aimed to create a happy and completing family and had to be based on clear conscience and maturity, so child marriage had to be avoided. Prof. Dr. Maria Farida Indrati, S.H., M.H. also stated that by still having the age limit of 16 for female to perform marriage, it would lead to more child marriage practice, considering that child marriage seemed to be a solution for people in low economic society. Based on the verdict, Prof. Dr. Maria Farida Indrati, S.H., M.H. also considered that child marriage could lead to several effects towards female, such as premature labor, the potential of giving birth to a child with the lack of nutrition, and bigger chances to be contracted by servical cancer. However, the court still decided to refuse the request to change the age limit in the Indonesian Marriage Act [7].

\subsection{Analysis on How Judicial Review on Gender-Biased Legislations in Indonesia is affected by the Female Judge Representation in the Indonesian Constitutional Court}

Based on the history of female judge in the Indonesian Constitutional Court, Indonesia has only had one female judge since the beginning of the court's establishment in 2003. This shows that the female representation of judge in the Indonesian Constitutional Court only covers 1 out of 9 judges in total. The lack of female representation in the Indonesian Constitutional Court affects the decision making in the judicial review process. The effect is significantly shown on one of the case examples above regarding the age limit in the Indonesian Marriage Act. The verdict shows that Prof. Dr. Maria Farida Indrati, S.H., M.H. has given opinions based on scientific and social facts, as well as future projection on how not raising the age limit may affect young women, however it was out of consideration that the court decided to refuse the request to raise the age limit. The decision was somehow still based on majority votes, created by the rest of the judges who were male, without considering the rights of young female. If such thing happens in the future, there will be more legislations reviewed, denied, or accepted without any considerations of female point of view. This will narrow women's rights in getting involved in society and to be guaranteed by the legislations. Another thing that needs to be considered is that the Indonesian Consitutional Court creates decisions based on the Indonesian Constitution of 1945 Article 28A, meaning that the constitution itself has guaranteed the rights to live for Indonesian citizens, regardless of their sexes. By limiting women's rights through the results of judicial review, it maybe possible to consider the verdict as violating the human rights guaranteed in the Indonesian Constitution.

\section{Conclusions}

In conclusion, the Constitutional Court of Indonesia still suffers from gender inequality and this problem is caused by the imbalance of female and male judges representation in the court. This imbalance affects several processes occurring at the court, including the judicial review process. The gender imbalance in the judge panel of the Indonesian Constitutional 
Court may affect the judicial review process that the result may lead to a gender biased verdict. In order to avoid such thing to happen, one of the things that needs to be considered is the amount of female representation in the Indonesian Constitutional Court judge panel. It is important to have equal amount of judges between male and female in the Constitutional Court, especially in order to eliminate gender biased legislations through the judicial review process.

\section{References}

1. Mahkamah Konstitusi Republik Indonesia (n.d.) Sejarah Pembentukan Mahkamah Konstitusi (the History of Constitutional Court Formation), retrieved July 25, 2018, from,

http://www.mahkamahkonstitusi.go.id/index.php?page=web.Mahkamah\&menu=2

2. Mahkamah Konstitusi Republik Indonesia (n.d.) Visi dan Misi (Vision and Mission), retrieved July 25, 2018, from, http://www.mahkamahkonstitusi.go.id/index.php?page=web.ProfilMK\&id=2\&menu=2

3. Ibid.

4. Mahkamah Konstitusi Republik Indonesia (n.d.) Hakim Konstitusi (Constitutional Judges), retrieved July 25, from, http://www.mahkamahkonstitusi.go.id/index.php?page=web.Hakim\&menu=3

5. A. Wirdana, Indonesia to Lose First and Only Female Constitutional Court Justice, retrieved July 25, 2018, (from, http://indonesiaexpat.biz/topreads/indonesia-losefemale-court-justice/ 2017)

6. The Republic of Indonesia. Verdict No. 46/PUU-VIII/2010.

7. The Republic of Indonesia. Verdict No. 30-74/PUU-XII/2014. 